\title{
Growth and Yield of Lettuce (Lactuca sativa L.) Under Organic Cultivation
}

DOI: $10.18196 / p t .2017 .073 .127-131$

\author{
Mujiono $^{1 *}$, Suyono ${ }^{2}$, and Purwanto ${ }^{1}$ \\ ${ }^{1}$ Agrotechnology Department, Faculty of Agriculture, Jenderal Soedirman University \\ ${ }^{2}$ Agribusiness Departement, Faculty of Agriculture, Jenderal Soedirman University \\ Jl. Dr. Soeparno 61 Karangwangkal, Purwokerto Central Java Indonesia, 53123, \\ *Corresponding author, email: mujiono_wd@yahoo.com
}

\begin{abstract}
This research was conducted to understand the technology of organic lettuce cultivation using liquid organic fertilizer and pesticide on the production of lettuce. Study was arranged in completely randomized design (CRD) with two treatments and 16 replicates. The treatments were P1 (goat manure + 6 $\mathrm{ml} / \mathrm{l}$ of SO Kontan LQ Liquid Organic Fertilizer for soil (LOF) + $6 \mathrm{ml} / \mathrm{l}$ of SO-Kontan Fert. LOF for leaf + 6\% of maja-gadung botanical pesticide + $10 \mathrm{~g} / \mathrm{plant}$ of biological agent Trichoderma harzianum) and P2 (goat manure $+6 \mathrm{~m} / / \mathrm{l}$ of SO-Kontan LQ LOF + $6 \mathrm{ml} / \mathrm{l}$ of SO-Kontan Fert. LOF + 6\% of maja-gadung botanical pesticide + bamboo leaves $+10 \mathrm{~g} /$ plant of biological agent $T$. harzianum. Results showed that the P2 was more effective than P1 for all variables of growth and yield, except the green colour of leaves. The preferable technology of LOF and botanical pesticide in organic lettuce cultivation was the P2 (goat manure $+6 \mathrm{~m} / / \mathrm{l}$ of SO-Kontan LQ soil LOF Lq $+6 \mathrm{ml} / \mathrm{l}$ of SO-Kontan Fert. LOF + 6\% of maja-gadung botanical pesticide + bamboo leaves + $10 \mathrm{~g} /$ plant of biological agent T. harzianum as indicating by productivity in $87.17 \mathrm{~g}$ per plant.

Keywords: Organic lettuce, Cultivation, Assembly, Liquid ogranic fertilizer (LOF), Botanical pesticide
\end{abstract}

\begin{abstract}
ABSTRAK
Penelitian ini bertujuan untuk mengetahui teknologi budidaya selada organik berbasis pupuk organik cair dan pestisida nabati yang menghasilkan komponen pertumbuhan tertinggi. Rancangan yang digunakan adalah Rancangan Acak Lengkap (RAL) dengan 2 perlakuan dan 16 ulangan. Perlakuan yang digunakan yaitu P1 (pupuk kendang kambing + POC tanah SO-kontan Lq (6 m//l) + POC daun SO-Kontan Fert (6 m//I) + Pestisida nabati maja gadung (6\%) + agens hayati Trichoderma harzianum (10 g/polybag), dan P2 ( pupuk kendang kambing + POC tanah SO-kontan Lq (6 ml//) + POC daun SO-Kontan Fert (6 m/l/) + Pestisida nabati maja gadung (6\%) + agens hayati Trichoderma harzianum (10 g/plant) + daun bamboo). Hasil penelitian menunjukkan bahwa teknologi budidaya selada organik berbasis pupuk organik cair dan pestisida nabati yang terbaik adalah rakitan P2 (pupuk kandang (10 ton/ha) + POC tanah SO-kontan Lq (6 m//I) + POC daun SO-Kontan Fert (6 m//l) + Pestisida nabati maja gadung (6\%) + agens hayati Trichoderma harzianum (10 g/polybag) + daun bambu) dengan produksi $32.36 \mathrm{~g} /$ tanaman.

Kata kunci: Selada organik, Rakitan budidaya, Pupuk Organik Cair (POC), Pestisida nabati
\end{abstract}

\section{INTRODUCTION}

Lettuce (Lactuca sativa L.) is a group of leafy vegetables that are well known in the community. The prospect of market absorption on lettuce commodities will increase corresponding to the increase in population, the level of community education, income and welfare of society, and the public's preference for lettuce (Samadi, 2014). Lettuce production fluctuates, but in Indonesia its production tends to decline in recent years, in 2013 its production was 635,728 and decreased to 602,468 tons in 2014 (Ministry of Agriculture, 2015).

Currently, the efforts for increasing lettuce production mostly conducted by intensifica- tion such as using excessive inorganic fertilizers and synthetic chemical pesticides, it makes farmers depend on fertilizers and pesticides. Intensive uses of inorganic fertilizers could not increase the productivity, and tended to reduce soil empowerment and health. According to Adiningsih (2005), the major key to improve soil health is increasing the content of soil organic materials, because of the low content of organic matter will reduce the nutrient carrying capacity and less efficient in using fertilizer because most of the nutrient components will disappear from the root environment. According to Sugito and Nuraini (2002), organic fertilizers are capable on 
increasing the absorption of $\mathrm{N}$ component up to $55 \%$ by increasing the yield until 10\%.

The previous research has produced two best technology assemblies in cultivation of organic lettuce among seven tested cultivation technologies, namely the assemblies containing components such 1) goat manure + SO Kontan Lq soil LOF $(6 \mathrm{ml} / \mathrm{l})+$ combined SO Kontan Fert leaf LOF $(6 \mathrm{ml} / \mathrm{l})+$ maja-gadung botanical pesticide $(6 \%)+$ bamboo leaves + biological agent $T$. harzianum (10 g/plant) (Mujiono, 2015) and 2) goat manure + SO-Kontan LQ soil LOF Lq $(6 \mathrm{ml} / \mathrm{l})$ + combined SO-Kontan Fert leaf LOF $(6 \mathrm{ml} / \mathrm{l})$ + maja-gadung botanical pesticide $(6 \%)+$ bamboo leaves + biological agent Trichoderma harzianum (10 g/plant) (Mujiono, 2015).

Uses of bamboo leaves as a mixture material for planting medium has numerously carried out. These leaves have many benefits in agriculture. The result of phytochemical observations on the bamboo leaves shows that they contain $1.56 \%$ phenol, $29 \%$ fatty acid, $27.03 \%$ methyl ester, $12.13 \%$ linolenate, and $3.62 \%$ phytol (Rahayu et al., 2011). This research was conducted to understand selected technology assembly in the organic lettuce using LOF and botanical pesticide.

\section{MATERIALS AND METHODS}

The research was conducted from May to October 2016 at screen house in Windujaya Village, Kedungbanteng Sub District, Banyu. The research was conducted by using an experimental method with Complete Randomized Design (CRD) containing two treatments and 16 replicates. The treatments were technology assemblies of organic lettuce cultivation based on LOF and botanical pesticide. They were P1 (goat manure + SO-Kontan LQ soil Liquid Organic Fertilizer (LOF) $(6 \mathrm{ml} / \mathrm{l})+$ combined SO-Kontan
Fert leaf LOF $(6 \mathrm{ml} / \mathrm{l})+$ maja-gadung botanical pesticide $(6 \%)+$ biological agent Trichoderma harzianum (10 g/plant) and P2 (goat manure + SO-Kontan LQ soil LOF Lq $(6 \mathrm{ml} / \mathrm{l})+$ combined SO-Kontan Fert leaf LOF (6 ml/l) + maja-gadung botanical pesticide $(6 \%)+$ bamboo leaves + biological agent Trichoderma harzianum (10 g/plant).

Variables observed were plant height, leaf numbers, leaf green level, leaf index, width of stomatal opening, fresh root weight, dry root weight, root volume, and root length. Data obtained from the research were analyzed by using analyses of variances, the data of significantly different treatments were further tested by Duncan's multiple range test (Duncan Multiple).

\section{RESULTS AND DISCUSSIONS}

The results showed that almost all of growth and yield components performed by assembly of organic lettuce cultivation technology was highly significant on variables of plant height, leaf numbers, fresh plant weight, dry plant weight, fresh root weight, dry root weight, root volume, and root length, whereas the treatments showed significantly different on the variables of leaf extent and width of the stomata opening, and insignificantly different on the leaf green level (Table 1).

Table 1. The Growth and Yield of Lettuce

\begin{tabular}{|c|c|c|c|c|}
\hline No. & Variable & Result & $\mathrm{CV}$ & Notes \\
\hline 1 & Plant height & ** & 11.68 & Highly significan \\
\hline 2 & Leaf quantity & $* *$ & 11.68 & Highly significan \\
\hline 3 & Leaf greenness & NS & 15.88 & Not significant \\
\hline 4 & Leaf area & * & 11.77 & Significant \\
\hline 5 & $\begin{array}{l}\text { Width of stomatal } \\
\text { opening }\end{array}$ & * & 17.83 & Significant \\
\hline 6 & Fresh root weight & ** & 24.80 & Highly significan \\
\hline 7 & Dry root weight & $* *$ & 21.49 & Highly significan \\
\hline 8 & Root volume & $* *$ & 24.21 & Highly significan \\
\hline 9 & Root length & ** & 28.92 & Highly significan \\
\hline 10 & Fresh plant weight & $* *$ & 17.74 & Highly significant \\
\hline 11 & Dry plant weight & $* *$ & 23.53 & Highly significant \\
\hline
\end{tabular}

Note: ${ }^{* *} p$ value $<0.01 ;{ }^{*} p$ value $<0.05$ 


\section{Growth Component Variables}

The treatment of assembly in the organic lettuce cultivation technology influenced highly significant difference on all variables of organic lettuce plant growth, except the leaf greenness which the variable observations can be seen in Figure 1.

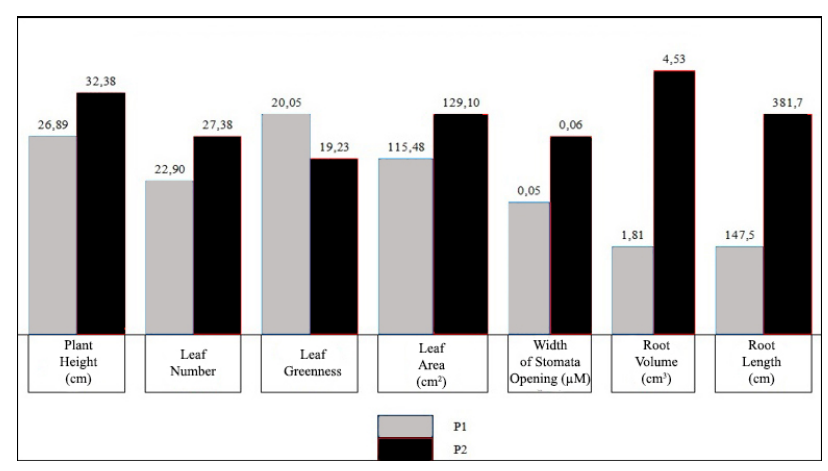

Note:

Figure 1. Growth variables on plant growth

P1 = goat manure $+6 \mathrm{ml} / \mathrm{l}$ of SO Kontan LQ Liquid Organic Fertilizer for soil (LOF) +6 $\mathrm{ml} / \mathrm{l}$ of SO-Kontan Fert. LOF for leaf $+6 \%$ of maja-gadung botanical pesticide + $10 \mathrm{~g} /$ plant of biological agent Trichoderma harzianum

$\mathrm{P} 2=$ goat manure $+6 \mathrm{ml} / /$ of SO-Kontan LQ LOF $+6 \mathrm{ml} / /$ of SO-Kontan Fert. LOF + $6 \%$ of maja-gadung botanical pesticide + bamboo leaves $+10 \mathrm{~g} /$ plant of bio logical agent $T$. harzianum

\section{Plant height}

This variable is observed as many as 12 times by three days interval and the results vary. The

P2 assembly using bamboo leaf mulch performed better result when compared with P1 at the last observation (Figure 1). This may be due to that the content of bamboo leaves is capable to increase the lettuce plant height. Purwono and Purnamawati (2007) stated that bamboo leaves contained elements of $\mathrm{P}$ and $\mathrm{K}$ to form and to transport carbohydrate, as a catalysator in protein formation and to regulate many mineral elements.

\section{Leaf quantity}

Based on Anova, the assembly treatment affects strongly to the leaf quantity variable. Leaf number means on the last observation show that the P2 assembly is 27.38 leaves greater than P1 having 22.90 leaves (Figure 1).
The difference between P1 and P2 is on the use of bamboo leaf mulch which causes the organic material sources on the $\mathrm{P} 2$ treatment are greater. The presence of the fungus T. harzianum and SO-Kontan Lq LOF as catalisators for organic matter degradation enables potential of plant growth to rise. This is supported by $\mathrm{Mu}-$ jiono (2011) statement to explain that T. harzianum gives roles in the process of organic matter decomposition, so the plants will absorb more numerous nutrition.

\section{Leaf greenness}

Result of Anova shows that the assembly treatment does not influence significantly to the leaf greenness (Table 1). This may be assumed due to magnesium element $(\mathrm{Mg})$ functions as the central element to form chlorophyll has been available in the planting medium. The product quality of fresh lettuce preferred by consumers is when the leaf greenness showing not so high.

\section{Width of stomatal opening}

Width of stomatal opening on the P2 assembly is higher than the $\mathrm{P} 1$ one. This may be presumed that there was an increasing temperature at the P2 assembly. Planting medium at the P1 assembly which did not use bamboo leaves tended to give blacker in color when compared with the P2 assembly, so it caused higher temperature at the P2 assembly. Bamboo leaves tended to absorb and to keep heat from surroundings, resulting in narrower width of stomatal opening for suppressing transpiration and dehydration. This is powered by Haryanti (2010) stated that stomatal width was closely related to the plant transpiration level to adapt with the environment.

\section{Leaf area}

Result of Anova shows that the treatment af- 
fects significantly on the leaf area variable (Table 1). The measurement on it performs that the P2 treatment gives better result than P1 as seen in Figure 1. Leaf area is closely concerned with the ability of plants to grow and develop in their life cycle particularly on the phase of root initiation. This result is strengthen by Purwono and Purnamawati (2007) stating that bamboo leaves contain many P element. P element in the phosphate ion is very useful for plants to stimulate root growth especially in initial growth.

\section{Root length}

Root length is measured by measuring all plant roots, also root quantity in a plant. Based on the Anova, the assembly treatments influence strongly on the root length (Table 1). The P2 assembly performs longer root length than the $\mathrm{p} 1$ assembly (Figure 1). This may be assumed that root growth and development are determined by the type of medium used. The P2 used bamboo leaves having hygroscopic trait to make the increase of soil porosity, resulting in root development.

\section{Root volume}

The root volume variable is determined by root length and root ability to absorb water in the planting medium. Root volume linearly relates to root length. The anova shows that the assembly treatments perform highly significant influence on root volume (Table 1). Planting medium at the P2 assembly used bamboo leaf mulch produced high hygroscopic level and water absorption. The condition causes the plants easily absorb water from the planting medium and oxygen is sufficient, so this will support secondary root development. Measurement of root volume at the P2 assembly is better than the P1 assembly (Figure 1).

\section{Yield components}

Yield variables comprise plant fresh and dry weights, fresh and dry root weights perform similar yield with growth variables. Figure 2 shows yield variables.

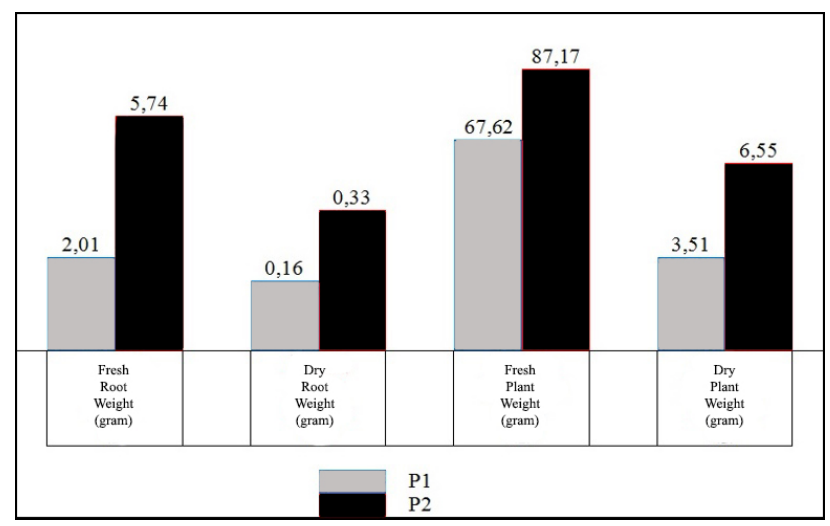

Figure 2. Means of component variables on lettuce plant yield

Note:

$\mathrm{P} 1=$ goat manure $+6 \mathrm{ml} / \mathrm{l}$ of SO Kontan LQ Liquid Organic Fertilizer for soil (LOF) +6 $\mathrm{ml} / \mathrm{l}$ of SO-Kontan Fert. LOF for leaf $+6 \%$ of maja-gadung botanical pesticide + $10 \mathrm{~g} /$ plant of biological agent Trichoderma harzianum

$\mathrm{P} 2=$ goat manure $+6 \mathrm{ml} / \mathrm{l}$ of SO-Kontan LQ LOF $+6 \mathrm{ml} / \mathrm{l}$ of SO-Kontan Fert. LOF + $6 \%$ of maja-gadung botanical pesticide + bamboo leaves $+10 \mathrm{~g} /$ plant of bio logical agent T. harzianum

\section{Fresh root weight}

The Anova shows that the assembly treatments strongly affect on the fresh root weight (Table 1). The highest root weight was found on the P2 assembly treatment (Figure 2). This may be due to high porosity on the planting medium using bamboo leaf mulch causing better growth and development of the roots when compared with root growth and development in the P1 assembly. Better growth and development of the roots lead to increasing root number and weight.

\section{Dry root weight}

Mean of dry root weight at the P2 assembly treatment reached 0.33 that was higher than P1 (0.16) (Figure 2). The Anova performs that different treatments gives highly significant to the dry root weight variable (Table 1). Dry weight forms accumulation of organic compounds produced by synthesis of organic compound, espe- 
cially water and carbohydrate depending on the photosynthesis rate of the plant (Lakitan, 1996). The P2 assembly contains bamboo leaves leading to much P element. According to Leiwakabessy et al., (2003), P element was important in generative growth plant root development.

Yield (weight of fresh or proper harvest plants)

Based on the Anova, the assembly treatments affect strongly to the yield or fresh plant weight. This implies that the treatments influence very significantly to the yield (Table 1 ). The highest yield (fresh plant weight or proper harvest weight) is found at the P2 assembly treatment, reaching $87.17 \mathrm{~g} /$ plant, whereas the P1 assembly only reaching $67.62 \mathrm{~g} /$ plant (Figure 2). Plant growth and development is closely related to the yield. Lettuce is a plant possessing economic value on its leaves as the vegetative component. Good growth gained at the P2 assembly will also determine lettuce plant yield variables, particularly on fresh plant weight.

\section{Dry plant weight}

The Anova performs that the assembly treatments significantly influence on dry plant weight (Table 1). Dry plant weight will be linearly related to fresh plant weight. The dry plant weight on the p2 assembly is greater than the P1 assembly (Figure 2). This can be caused the presence of bamboo leaves in the P2 assembly is capable to increase plant growth and development and also increase the net assimilation on the plant.

\section{CONCLUSION}

The research can be concluded preferable technology of LOF and botanical pesticide in organic lettuce cultivation was the P2 (goat manure $+6 \mathrm{ml} / \mathrm{l}$ of SO-Kontan LQ soil LOF Lq $+6 \mathrm{ml} / \mathrm{l}$ of SO-Kontan Fert. LOF $+6 \%$ of maja-gadung botanical pesticide + bamboo leaves $+10 \mathrm{~g} /$ plant of biological agent $T$. harzianum as indicating by productivity in $87.17 \mathrm{~g}$ per plant.

\section{REFERENCES}

Haryanti, S. 2010. Pengaruh naungan yang berbeda terhadap jumlah stomata dan ukuran porus stomata daun Zephyranthes Rosea lindl. Buletin Anatomi dan fiologi. 18 (1): 41-48.

Kementerian Pertanian. 2015. Data Produksi Hortikultura. Accessed on 28 Agustus 2016. https://aplikasi.pertanian. go.id/bdsp/hasil_kom.asp.

Lakitan, B. 1996. Fisiologi Pertumbuhan dan Perkembangan Tanaman. PT. Raja Grafindo Persada, Jakarta.

Leiwakabessy M., U.M. Wahjudin, Suwarno. 2003. Kesuburan Tanah. IPB Press, Bogor.

Mujiono, Suyono, dan Purwanto. 2015. Perakitan Teknologi Budidaya Selada Organik Berbasis Pupuk Organik Cair dan Pestisida Nabati. Seminar Nasional Dies Natalis UGM. Yogyakarta, 19 September 2015. 15 p. Suyono, Purwanto dan Tarjoko, 2011. Perakitan teknologi produksi padi organik berbasis pupuk organik cair dan pestisida nabati. Agroland 18 (3):162-168.

Purwono dan Purnamawati. 2007. Budidaya 8 jenis tanaman pangan unggul. Penebar Swadaya, Jakarta. 14p.

Rahayu, M. Bata dan A. Marsudi. 2011. Potensi Ekstrak Daun Bambu Sebagai Antibakteri Dalam Susu Pedet PfhLepas Kolostrum.Balitbang pertanian. $34 \mathrm{p}$.

Samadi, B. 2014. Rahasia Budidaya Selada. Pustaka Mina, Jakarta. $110 \mathrm{p}$.

Sugito, Y.dan Y. Nuraini. 2002. Sistem Pertqanian Organik. Dalam Soecipto, M.C. Mahfud dan M. Ali Yusron (Eds.). Seminar Hasil Penelitian Teknologi Pertanian Untuk Mendukung Ketahanan Pangan Berwawasan Agribisnis. Malang, 8-9 Agustus 2002. 24 p. 